\title{
Roosting ecology and morphometric analysis of Pteropus medius (Indian flying fox) in Lower Dir, district, Pakistan
}

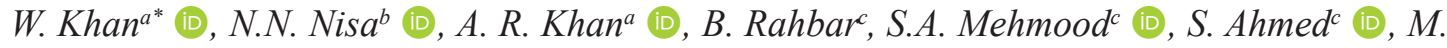 \\ Kamald (D), M. Shahe (D), A. Rasoole (D), W.A. Pahanwarf (D), I. Ullah $^{g}$ and S. Khan ${ }^{a}$

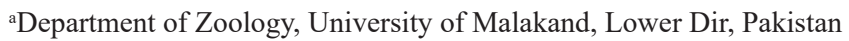

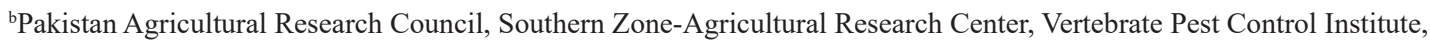 \\ University Campus, Karachi, Pakistan \\ 'Department of Zoology, Hazara University, Mansehra, Pakistan \\ ${ }^{\mathrm{d}}$ Department of Zoology, University of Karachi, Karachi-Pakistan

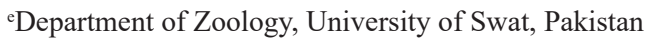

${ }^{\mathrm{f}}$ Department of Zoology, Shah Abdul Latif University Khairpur Miris Sindh, Pakistan

${ }^{g}$ Department of Biological Sciences Karakuram, International University Gilgit, Pakistan *e-mail: walikhan.pk@gmail.com

Received: March 28, 2019 - Accepted: May 21, 2019 - Distributed: February 28, 2021

\begin{abstract}
The present study was conducted to explore morphometric variations of Pteropus medius (the Indian flying fox) and the roosting trees in Lower Dir, Pakistan. The bats were captured from Morus alba, Morus nigra, Brousonetia papyrifera, Pinus raxburghii, Hevea brasiliensis, Platanus orientalis, Populous nigra, Melia azedarach, Eucalyptus camaldulensis and Grevillea robusta through sling shot and mess net methods. A total of 12 bats were studied for the differential morphological features based on age and sex. Male bats were recorded higher in weight than females. The variations were found in body mass $(821.1+34.65 \mathrm{gm})$, circumference of body with wings $(25.43+0.39 \mathrm{~cm})$, wingspan $(112.58+1.90 \mathrm{~cm})$, Body length $(20.73+0.68 \mathrm{~cm})$, Snout length $(3.42+0.04 \mathrm{~cm})$, Eye length $(1.45+0.033 \mathrm{~cm})$, Length of ear $(3.56+0.05 \mathrm{~cm})$, Width of ear $(2.46+0.04 \mathrm{~cm})$, Length $\mathrm{b} / \mathrm{w}$ ear $(5.51+0.11 \mathrm{~cm})$, Circumference of neck $(12.23+0.24 \mathrm{~cm})$, Circumference of body without wings $(18.68+0.31 \mathrm{~cm})$, Arm wing length $(23.2+1.03 \mathrm{~cm})$, Length of thumb $(5.43+0.1 \mathrm{~cm})$, Length of nail $(1.89+0.05 \mathrm{~cm})$, Hand wing length $(29.1+0.51 \mathrm{~cm})$, Maximum width of wing $(21.03+0.68 \mathrm{~cm})$, Length b/w tip of wing to $5^{\text {th }}$ digit $(29.39+0.30 \mathrm{~cm})$, Length $\mathrm{b} / \mathrm{w} 5^{\text {th }}$ digit to foot $(22.97+1.09 \mathrm{~cm})$, Length $\mathrm{b} / \mathrm{w}$ feet $(18.31+0.74 \mathrm{~cm})$ and Length of foot claw $(4.23+0.05 \mathrm{~cm})$. This study was designed for analysis of external morphological variations for P.medius (the Indian flying fox) that may help in identification of these bats and their roosting sites.
\end{abstract}

Keywords: Pteropus medius, morphometric variations, body mass, circumference of body, wingspan, body length, roosting trees.

\section{Ecologia de roosting e análise morfométrica de Pteropus medius (raposa-voadora indiana) no distrito de Lower Dir, Paquistão}

\section{Resumo}

O presente estudo foi conduzido com o intuito de explorar variações morfométricas de Pteropus medius (raposa-voadora indiana) e árvores de repouso em Lower Dir, Paquistão. Os morcegos foram capturados de Morus alba, Morus nigra, Broussonetia papyrifera, Pinus roxburghii, Hevea brasiliensis, Platanus orientalis, Populus nigra, Melia azedarach, Eucalyptus camaldulensis e Grevillea robusta por meio de estilingues e redes. Doze morcegos foram estudados quanto às características morfológicas diferenciais com base na idade e no sexo. Os morcegos machos apresentaram maior peso do que as fêmeas. As variações foram encontradas em massa corporal $(821,1+34,65 \mathrm{~g})$, circunferência do corpo com asas $(25,43+0,39 \mathrm{~cm})$, envergadura $(112,58+1,90 \mathrm{~cm})$, comprimento do corpo $(20,73+0,68 \mathrm{~cm})$, comprimento do focinho $(3,42+0,04 \mathrm{~cm})$, comprimento do olho $(1,45+0,033 \mathrm{~cm})$, comprimento da orelha $(3,56+0,05 \mathrm{~cm})$, largura da orelha $(2,46+0,04 \mathrm{~cm})$, comprimento entre as orelhas $(5,51+0,11 \mathrm{~cm})$, circunferência do pescoço $(12,23+0,24 \mathrm{~cm})$, circunferência do corpo sem asas $(18,68+0,31 \mathrm{~cm})$, comprimento da asa da pata dianteira $(23,2+1,03 \mathrm{~cm})$, comprimento do polegar $(5,43+0,1 \mathrm{~cm})$, comprimento da unha $(1,89+0,05 \mathrm{~cm})$, comprimento da asa até a ponta do dedo $(29,1+0,51 \mathrm{~cm})$, largura máxima da asa $(21,03+0,68 \mathrm{~cm})$, comprimento entre a ponta da asa e o quinto dedo $(29,39+0,30 \mathrm{~cm})$, comprimento entre o quinto dedo e a pata $(22,97+1,09 \mathrm{~cm})$, comprimento entre as patas $(18,31+0,74 \mathrm{~cm})$ e comprimento da garra da pata $(4,23+0,05 \mathrm{~cm})$. Este estudo foi desenvolvido para análise de variações morfológicas externas de $P$. medius (raposa-voadora indiana) e pode auxiliar na identificação desses morcegos e seus locais de nidificação.

Palavras-chave: Pteropus medius, variações morfométricas, massa corporal, circunferência do corpo, envergadura, comprimento do corpo, roosting trees. 


\section{Introduction}

The bats exhibit a remarkable diversity and broad geographic range (Simmons, 2005). Bats are found everywhere in the world except Arctic, Antarctica and some islands (Hutson et al., 2001) and comprising 1,232 species representing a quarter of the total 5,487 mammal species (Schipper et al., 2008; Simmons 2010; Kunz et al., 2011). However, about 119 bat species found in the subcontinent including Pakistan (Bates and Harrison, 1997).

The roosting sites in Pakistan provides natural habitats for the survival of bat fauna (Perveen and Jamal, 2012; Perveen and Rahman, 2012). In Pakistan bats comprise about one fourth of the known mammalian species which comprise 50 species with 26 genera and 8 families (Roberts, 1997). Three genera and four species of Pteropodids bats including short nosed fruit bat (Cynopterus sphinx), the Indian flying fox (Pteropus giganteus), the Egyptian fruit bat (Rousettus aegyptiacus), and the fulvous fruit bat (Rousettus leshenaulti) are found in Pakistan (Roberts, 1997; Mahmood-ul- Hassan et al., 2009).

Pteropus giganteus, also known as Indian flying fox, is a fruit bat (Teeling et al., 2005). In Pakistan, this species has been reported from Rawal Lake, Saidpur and Margalla Hills in Islamabad, Sialkot, Lahore, Changa Manga and Renala Khurd in Punjab, and from Jacobabad, Shahpur and Clifton Railway Bridge in Karachi (Eates, 1968; Roberts, 1997; Bates and Harrison, 1997).

Pteropus giganteus is generally a colonial species and roost in large trees often in area with topographic features offer protection from strong winds, assist in thermoregulation and provide access to updrafts for easier flight (Cheke and Dahl, 1981; Pierson and Rainey, 1992; Richmond et al., 1998). Flying foxes acquire shelter and energy from plants and in turn disperse the pollen and seeds of the plants (Ganesh and Davidar, 2001). Roosts of Indian flying fox were also observed in forest plantations of Casurina species, Acacia species, and indigenous tree species like Ficus, Bauhinia, rain tree (Samanea saman) and Indian date (Tamarindus indica) (Chakravarthy and Yeshwanth Hm, 2008). Roosting site selection depends on their abundance, risk of predation, availability and distribution of food resources, body size and physical environment (Kunz, 1982).

Body measurements of the $P$. giganteus have been recorded by Roberts (1997), bates and Harrison (1997), Aziz et al. (2007) and Molur et al. (2007). Characters like body mass, wing morphology and forearm length may be designated important parameters for autecological considerations (Aeshita et al., 2006).

Flying foxes are declining word-wide (Mildenstein et al., 2005; Stier and Mildenstein, 2005) due to growing human populations and consequent demands for food and housing that cause destruction of bat habitat (Fujita and Tuttle, 1991; Mickleburgh et al., 2002). Farmers and biologists of Pakistan considered them as non-significant animal, therefore, less research has been conducted on bat fauna in Pakistan (Butt and Beg, 2001).This research was aimed to gather information on differential morphology and roosting trees of the Indian flying fox.

\section{Materials and Methods}

\subsection{Study area}

Lower Dir is located at North of Malakand and about $130 \mathrm{~km}$ from Peshawar (capital of the province) and $40 \mathrm{~km}$ away from Mingora, Swat. This area lies at 34, 6500 (3438'60.000”N), Latitude; 72, 0333 (721'59.880”E) longitude and $687 \mathrm{~m}$ altitude. The annual rainfall range from $(600 \mathrm{~mm}-1100 \mathrm{~mm})$ and average maximum and minimum temperature are about $29 \mathrm{C}^{0}$ and $12 \mathrm{C}^{0}$, respectively.

\subsection{Data collection}

Pteropus medius (Indian flying fox) were captured with the aid of net and slingshots. The samples were safely brought to the Laboratory of Parasitology, Department of Zoology, University of Malakand for morphometric analysis.

\subsection{Morphometric analysis}

The collected animals werekilled in a vacuum chamber by using cotton wetted with chloroform. All the specimens were measured with the aid of plastic ruler

\subsection{Roosting site analysis}

The bats colonies were counted through the direct roost count method (Herrera et al., 2008) on different trees and the data was saved in written form. The research area was periodically visited and bats were counted on different species of trees.

\subsection{Statistical analysis}

The recorded data were put in excel for statistical analysis and their corresponding results were mentioned in this paper.

\section{Results}

\subsection{Morphological characteristics (average) of Pteropus medius.}

Morphological observations shows that Indian flying fox is dark brown in colour with body weight $821.1+34.65 \mathrm{gm}$, body length: $20.73+0.68 \mathrm{~cm}$, snout is elongated and hairy: $3.42+0.04 \mathrm{~cm}$, ears are tall, black and pointed at tips: $3.56+0.05 \mathrm{~cm}$, width of ear: $2.46+0.04 \mathrm{~cm}$, length b/w ears: $5.51+0.11 \mathrm{~cm}$, eye length: $1.45+0.033 \mathrm{~cm}$, circumference of neck: $12.23+0.24 \mathrm{~cm}$, the wings are massive, long and pointed, circumference of body without wings: $18.68+0.31 \mathrm{~cm}$, arm wing length: $23.2+1.03 \mathrm{~cm}$, wingspan length: $112.58+1.90 \mathrm{~cm}$ and Circumference of body with wings: $25.43+0.39 \mathrm{~cm}$, width of wing: $21.03+0.68 \mathrm{~cm}$, hand wing length: $29.1+0.51 \mathrm{~cm}$, length of thumb is $5.43+0.1 \mathrm{~cm}$, the thumb or first digit has greater claw, while the claw of the second digit is small, length $\mathrm{b} / \mathrm{w}$ tip of wing to $5^{\text {th }}$ digit: $29.39+0.30 \mathrm{~cm}$, length of nail: $1.89+0.05 \mathrm{~cm}$, the feet are large with blunt claws, length $\mathrm{b} / \mathrm{w} 5^{\text {th }}$ digit to foot: $22.97+1.09 \mathrm{~cm}$, length $\mathrm{b} / \mathrm{w}$ feet: $18.31+0.74 \mathrm{~cm}$, length of foot claw length: $4.23+0.05 \mathrm{~cm}$. The males bats were calculated larger in size then females bats and measurements of external parameters were observed variable because of differences in age and sex. 
The pelage of this species is long, varies in color at the shoulder and ventral surface, independent of age, sex and climate variations. Its body weight and fore-arm length are the greatest than all collected bats. It is frugivorous or nectarivorous, i.e., it eat fruits or lick nectar from flowers. At dusk, it forages on ripe fruits, while ingesting pulp of fruits, it expels waste that pollinates and disperses seeds. It is gregarious and roosts in nature. The further details of morphometric variations are given in Table 1.

\subsection{Roosting trees}

The total number of bats (2844) were counted and roosting trees in this area observed were Grevillea robusta $(\mathrm{n}=3)$, Populous nigra $(\mathrm{n}=73)$, Platanus orientalis $(\mathrm{n}=8)$, Hevea brasiliensis (rubber tree, $\mathrm{n}=1)$, Pinus raxburghii $(\mathrm{n}=9)$, Brousonetia papyrifera $(\mathrm{n}=13)$, Orus nigra $(\mathrm{n}=8)$ and Morus alba $(\mathrm{n}=5)$, Melia azedarach (3), and Eucalyptus camaldulensis (12). The maximum average number of bats was counted on platanus orietalis (26.5) and minimum average number of bats was counted on melia azedarach (5). The seasonal changes in place and separate roosting and feeding sits (persimmon gardens) were observed. There were thousands of trees of populous nigra and even hundered of the other trees but in this paper those trees mentioned in which bat was observed and the number of trees and bats counting are given in Table 2 .

Table 1. Morphometric analysis of P.medius (the Indian flying fox) captured from lower Dir district, Pakistan ( $\mathrm{n}=12)$.

\begin{tabular}{lcc}
\hline \multicolumn{1}{c}{ Parameters name } & Average & Range \\
\hline Body weight $(\mathrm{gm})$ & $821.1+34.65$ & $570-946$ \\
Snout length $(\mathrm{cm})$ & $3.42+0.04$ & $3-3.5$ \\
Eye length $(\mathrm{cm})$ & $1.45+0.033$ & $1.1-1.5$ \\
Length of ear(cm) & $3.56+0.05$ & $3.3-3.9$ \\
Width of ear $(\mathrm{cm})$ & $2.46+0.04$ & $2.2-2.7$ \\
Length b/w ears(cm) & $5.51+0.11$ & $5-6$ \\
Circumference of neck (cm) & $12.23+0.24$ & $10.5-13$ \\
Body length $(\mathrm{cm})$ & $20.73+0.68$ & $17-25$ \\
Circumference of body without wings(cm) & $18.68+0.31$ & $16.7-20.5$ \\
Arm wing length $(\mathrm{cm})$ & $23.2+1.03$ & $16-30$ \\
Length of thumb $(\mathrm{cm})$ & $5.43+0.1$ & $5-5.8$ \\
Length of nail(cm) & $1.89+0.05$ & $1.7-2.2$ \\
Hand wing length(cm) & $29.1+0.51$ & $26-33$ \\
Maximum width of wing(cm) & $21.03+0.68$ & $17.3-25$ \\
Length b/w tip of wing to $5^{\text {th }}$ digit(cm) & $29.39+0.30$ & $28-32$ \\
Length b/w 5 ${ }^{\text {th }}$ digit to foot(cm) & $22.97+1.09$ & $17-30$ \\
Length b/w feet(cm) & $18.31+0.74$ & $15-24$ \\
Length of foot claw(cm) & $4.23+0.05$ & $4-4.5$ \\
Wingspan(cm) & $112.58+1.90$ & $98-120$ \\
Circumference of body with wings(cm) & $25.43+0.39$ & $22.2-27$ \\
\hline
\end{tabular}

Table 2. Roosting trees of P.medius (Indian flying fox) in Lower Dir district, Pakistan.

\begin{tabular}{|c|c|c|c|c|c|c|c|}
\hline Family & Roosting tree & $\begin{array}{c}\text { Common } \\
\text { name }\end{array}$ & Location of roost & $\begin{array}{l}\text { Number } \\
\text { of trees }\end{array}$ & $\begin{array}{c}\text { Colony } \\
\text { size }\end{array}$ & Range & Average \\
\hline Proteaceae & Grevillea robusta & Silky oak & Fishing hut & 3 & 56 & $9-28$ & 18.7 \\
\hline Salicaceae & Populous nigra & Black oplar & Sahsada and Fishing hut & 73 & 1701 & $5-43$ & 23.3 \\
\hline Platanaceae & Platanus orientalis & $\begin{array}{l}\text { Oriental } \\
\text { plane-tree }\end{array}$ & Sahsada and Fishing hut & 8 & 212 & $19-35$ & 26.5 \\
\hline Euphorbiaceae & Hevea brasiliensis & Rubber tree & Fishing hut & 1 & 25 & $0-25$ & 25 \\
\hline Pinaceae & Pinus raxburghii & Chirr pine & Fishing hut & 9 & 81 & $4-16$ & 9 \\
\hline \multirow[t]{3}{*}{ Moraceae } & $\begin{array}{l}\text { Brousonetia } \\
\text { papyrifera }\end{array}$ & paper mulberry & Sahsada and Fishing hut & 13 & 311 & $13-33$ & 23.92 \\
\hline & Morus nigra & Black Mulberry & Sahsada and Fishing hut & 8 & 195 & $21-28$ & 24.37 \\
\hline & Morus alba & White Mulberry & Sahsada and Fishing hut & 5 & 132 & $18-35$ & 26.4 \\
\hline Meliaceae & Melia azedarach & China berry & Sahsada and Fishing hut & 3 & 15 & $3-7$ & 5 \\
\hline Myrtaceae & $\begin{array}{l}\text { Eucalyptus } \\
\text { camaldulensis }\end{array}$ & river red gum & Fishing hut & 12 & 116 & $5-13$ & 9.66 \\
\hline
\end{tabular}




\section{Discussion}

The bats were identified on the basis of external morphology and measurements of different skull parameters (Hill and Smith, 1985; Vaughan et al., 2000; Jacobs et al., 2006) are still a highly reliable technique in most instances. The measurement of body mass of this species is large compared to other species and our result is similar to Simmons (2005) who stated that among all the bat species, P. giganteus is the world largest bat due to their largest body size and weight. Our results about average body weight of Pteropus medius $(821.1+34.65 \mathrm{gm})$, body length $(20.73+0.68 \mathrm{~cm})$, wingspan $(112.58+1.90 \mathrm{~cm})$ and males were larger than females are similar to (Marimuthu, 1998; Nowak, 1999; Thatcher, 2004;"'Greater Indian Fruit Bat (Indian Flying Fox)", 2002) body mass of this species ranges from 600 to 1600 and males are generally larger than females, wingspan may ranges from 1.2 to $1.5 \mathrm{~m}$ and body length average $23 \mathrm{~cm}$. In our collections some bats were exactly $23 \mathrm{~cm}$ body length but the slightly difference is due to age and sex. Thumbs were observed for hanging to trees in this species in study area and the same view was given by Bennett (1993) that the pendent postures of mega chiropteran are hanging from one or both feet facilitated by locking mechanism.

In Pakistan P.giganteus was reported by Murray (1884) and Eates (1968) from Malir in Karachi. However, we were observed P.medius in Dir district. Moreover, it was reported from Mohlandar Mango Garden, Governor House, Jhelum in Multan, Mailsi in Punjab and Malakand in Pakistan by Roberts (1997).

Khan (1985) claims the largest colony of Indian Flying fox in Bangladesh with 2500 individual of bats while we were observed 2844 individual in the roosting trees: Grevillea robusta, Populous nigra, Platanus orientalis, Hevea brasiliensis, Pinus raxburghii, Brousonetia papyrifera, Morus nigra, Morus alba,Melia azedarach, and Eucalyptus camaldulensis.

Over 6000 individuals of Indian flying fox colony was reported in Nallur near Chennai, Tamil Nadu (Smith, 1998). In present study all the roosting sites were located near water sources like rivers and streams of Lower Dir district, Pakistan. Most of the authors have been reported the same view that roosts commonly are found close to water (Fenton and Barclay, 1980; Kunz, 1982; Herd and Fenton, 1983; Thomas, 1988; Brigham et al., 1992).

Bats generally prefer to roost during daytime in diversified roosting habitats. Roosting site selection depends on their abundance, risk of predation, availability and distribution of food resources, body size and physical environment (Kunz, 1982). Bates and Harrison (1997) described as $P$. giganteus always roost near human settlements.

Vendan et al. (2011) were observed $P$. giganteus on Albizia lebbek, Artocarpus integrifolia, Azadirachta indica, Cocos nucifera, trees Dilonex regia, Eucalyptus globules, Eugenia jambolana, Ficus benjamina, F.glomerata, F. religiosa Mangifera indica, Millingtonia hortensis, Peltophorum ferrugineum, Tamarindus indica, Polyalthia longifolia, Terminalia cattapa and Toona ciliate while in present observation these bats have been observed on tall trees: Grevillea robusta, Populous nigra, Platanus orientalis, Oinus raxburghii, and Eucalyptus camaldulensis in river site, similar observation was made by Richardson (1990).

The trees that provided great protection from environmental hazardous were more populated; help in flights and the same view were given by (Pierson \& Rainey, 1992; Richmond et al., 1998). These bats use near fruits gardens for food during night time that are separated from their roosting sits and the same behavior selecting feeding and roosting sits separate has noted for other pteropus species (Pierson \& Rainey 1992). P.giganteus were migrated to other place in winter for food and according to (Pierson \& Rainey 1992) seasonal migration of Pteropus tend to be related to birthing season and (Nelson, 1965) migration is due to food abundance.

\section{Conclusions}

P.medius show variation in external morphological features due to age and sex differences, use separate feeding and roosting sits as well as diverse roost.

\section{References}

AESHITA, M., WILSKE, B., ZHAN-HUI, T. and CHEN, J., 2006. Occurrence and morphometric variability in the frugivorous bat species, Cynopterus sphinx and Rousettus leshenaulti, from a tropical rainforest, Xishuangbanna, SWChina. Acta Chiropterologica, vol. 8, no. 2, pp. 417-427. http://dx.doi.org/10.3161/17335329(2006)8[417:OAMVIT]2.0.CO;2.

AZIZ, M.A., REZA, A.H.M.A., HASAN, M.K., TONCHANGA, P.K., SARKER, A., ATIQUZZAMAN, K.M., DUTTA, S. and RAHMAN, K.M.Z., 2007. Some notes on three species of bats of Jahangir Nagar University, Bangladish. Zoos' Print Journal, vol. 26, no. 6, pp. 2729-2731. http://dx.doi.org/10.11609/JoTT. ZPJ.1487.2729-31.

BATES, P. and HARRISON, D. 1997. Bats of the Indian Subcontinent. Harrison, UK: Harrison Zoological Museum, pp. 123-258.

BENNETT, M., 1993. Structural modifications involved in the fore and hind limb grip of some flying foxes, Chiroptera: pteropodidae. Journal of Zoology, vol. 229, no. 2, pp. 237-248. http://dx.doi.org/10.1111/j.1469-7998.1993.tb02633.x.

BRIGHAM, R.M., ALDRIDGE, H.D. and MACKEY, M., 1992. Variation in habitat use and prey selection by yuma bats, Myotis yumanensis. Journal of Mammalogy, vol. 73, no. 3, pp. 640-645. http://dx.doi.org/10.2307/1382036.

BUTT, A. and BEG, M.A., 2001. Description of two new species of spiders of the families Clubionidae and Oxyopidae from Pakistan. Pakistan Journal of Zoology, vol. 33, pp. 35-37.

CHAKRAVARTHY, A.K. and YESHWANTH HM, K., 2008. Status of roost of Indian fruit bat (Pteropus giganteus) in Karnataka, South India. CCINSA, vol. 9, pp. 16-18.

CHEKE, A.S. and DAHL, J.F., 1981. The status of bats on western Indian Ocean islands, with special reference to Pteropus. Mammalia, vol. 1, no. 2, pp. 205-238. http://dx.doi.org/10.1515/ mamm.1981.45.2.205. 
EATES, K.R., 1968. An introduction to the vertebrate fauna of Sindh and Khairpur State, Written in 1952 and published in West Pakistan. Gazetteer-sindh Region, Government of Pakistan, Chapter III, part I. Mammalia, pp. 33-52.

FENTON, M.B. and BARCLAY, R.M.R., 1980. Myotis lucifugus. Mammalian Species, vol. 142, no. 1, pp. 1-8. http://dx.doi. org/10.2307/3503792. PMid:7405858.

FUJITA, M.S. and TUTTLE, M.D., 1991. Flying foxes (Chiraptera: Pteropodidae): threatened animals of key ecological and economic importance. Conservation Biology, vol. 5, no. 4, pp. 455-463. http://dx.doi.org/10.1111/j.1523-1739.1991.tb00352.x.

GANESH, T. and DAVIDAR, P., 2001. Dispersal modes of tree species in the wet forests of southern Western Ghats. Current Science, vol. 80, pp. 394-399.

HERD, R.M. and FENTON, M.B., 1983. An electrophoretic morphological and ecological investigation of a putative hybrid zone between Myotis lucifugus and Myotis yumanensis (Chiroptera: vespertilionidae). Canadian Journal of Zoology, vol. 61, no. 9, pp. 2029-2050. http://dx.doi.org/10.1139/z83-268.

HERRERA, E.A., KUNZ, T.H. and MUNOZA, M.R., 2008. Roosting behaviorand group stability of the big fruit-eating bat Artibeus (Chiroptera: phyllostmatidae). Mammalian Biology, vol. 73, no. 3, pp. 214-222. http://dx.doi.org/10.1016/j.mambio.2007.05.013.

HILL, J.E. and SMITH, J.D., 1985. Bats a natural history. Austin: Texas University Press.

HUTSON, A.M., MECKLENBURG, S.P. and RACEY, P.A., 2001. Microchiropteran bats: globl status survey and conservation action plan. Switzerland and Cambridge, UK: IUCN/SSC Chiroptera Specialist Group. Gland, pp. 1-258. http://dx.doi.org/10.2305/ IUCN.CH.2001.SSC-AP.1.en.

JACOBS, D.S., EICK, G.N., SCHOEMAN, M.C. and MATTHEE, C.A., 2006. Cryptic species in an insectivorous bat. Scotophilus Dinganii. Journal of Mammalogy, vol. 87, no. 1, pp. 161-170. http://dx.doi.org/10.1644/04-MAMM-A-132R2.1.

KHAN, R., 1985. Mammals of Bangladesh. Dhaka: Nazma Reza, $92 \mathrm{p}$.

KUNZ, T.H., 1982. Roosting ecology. In: T.H. KUNZ, ed. Ecology of bats. New York: Plenum publishing, pp. 1-55.

KUNZ, T.H., ELIZABETH, B.T., DANA, B., LOBOVA, T. and FLEMING, T.H., 2011. Ecosystem services provided by bats. Annals of the New York Academy of Sciences, vol. 1223, no. 1, pp. 1-38. http://dx.doi.org/10.1111/j.1749-6632.2011.06004.x. PMid:21449963.

MAHMOOD-UL-HASSAN, M., JONES, M.G., and DEITZ, C., 2009. The bats of Pakistan, the least known creature. Saarbrucken: Verlag Dr. Muller, 168 p.

MARIMUTHU, G., 1998 [viewed 19 October 2004]. The Sacred Flying Fox of India. Bats [online], vol. 9, no. 2, pp. 10-11. Available from: http://www.batcon.org/resources/media-education/ bats-magazine/bat_article/324?tmpl=component

MICKLEBURGH, S.P., HUTSON, A.M. and RACEY, P.A., 2002. A review of the global conservation status of bats. Oryx, vol. 36, no. 1, pp. 18-34. http://dx.doi.org/10.1017/S0030605302000054.

MILDENSTEIN, T.L., STIER, S.C., NUEVO-DIEGO, C.E., MILLS, L.S. and NUEVODIEGO, C., 2005. Habitat selection of endangered and endemic large flying-foxes in Subic Bay, Philippines. Biological Conservation, vol. 126, no. 1, pp. 93-102. http://dx.doi.org/10.1016/j.biocon.2005.05.001.
MOLUR, S., MOLUR, P. and RAVICHANDRAN, B., 2007. Electrocuted flying fox in Madicari. Coorg. Bat Net, vol. 8, no. $1-2,44 \mathrm{p}$

MURRAY, J.A., 1884. The vertebrate zoology of Sind. London, UK: Richardson and Co., pp. 1-424.

NELSON, J., 1965. Movements of Australian flying foxes (Pteropodidae: megachiroptera). Australian Journal of Zoology, vol. 13, no. 1, pp. 53-73. http://dx.doi.org/10.1071/ZO9650053.

NOWAK, R., 1999. Walker's Mammals of the world. Baltimore and London: The Johns Hopkins University Press.

PERVEEN, F. and RAHMAN, F., 2012 Checklist of first recorded bats species in Peshawar \& adjacent areas, Khyber Pakhtunkhwa. International Journal of Farming \& Allied Sciences, vol. 1, no. 4, pp. 97-100.

PERVEEN, F. and JAMAL, A., 2012. Checklist of spider fauna of FR Peshawar, FATA, Pakistan. Arthropods., vol. 1, pp. 35-39.

PIERSON, E.D. and RAINEY, W.E., 1992. The biology of flying foxes of the genus pteropus: A review. In: D.E. WILSON and G.L. GRAHAM, eds. Pacific Island Flying Foxes: Proceedings of an International conservation Conference. Washington, DC: US Fish and Wildlife Service Biological Report, vol. 90, pp. 1-17.

RICHARDSON, E.G., 1990. The spectacled flying-fox, Pteropus conspicillatus (Chiroptera: Pteropodidae) in north Queensland. Roost sites and distribution patterns. Australian Mammalogy, vol. 13, pp. 17-24.

RICHMOND, J.Q., BANACK, S.A. and GRANT, G.S., 1998. Comparative analysis of wing morphology, flight behavior, and habitat use in fling foxes (Genus: pteropus). Australian Journal of Zoology, vol. 46, no. 3, pp. 283-289. http://dx.doi.org/10.1071/ ZO97059.

ROBERTS, T.J., 1997. Mammals of Pakistan: Revised edition. Oxford, UK: Oxford University Prees, pp. 1-56.

SCHIPPER, J., CHANSON, J.S., CHIOZZA, F., COX, N.A., HOFFMANN, M., KATARIYA, V., LAMOREUX, J., RODRIGUES, A.S., STUART, S.N., TEMPLE, H.J., BAILLIE, J., BOITANI, L., LACHER JUNIOR, T.E., MITTERMEIER, R.A., SMITH, A.T., ABSOLON, D., AGUIAR, J.M., AMORI, G., BAKKOUR, N., BALDI, R., BERRIDGE, R.J., BIELBY, J., BLACK, P.A., BLANC, J.J., BROOKS, T.M., BURTON, J.A., BUTYNSKI, T.M., CATULLO, G., CHAPMAN, R., COKELISS, Z., COLLEN, B., CONROY, J., COOKE, J.G., DA FONSECA, G.A., DEROCHER, A.E., DUBLIN, H.T., DUCKWORTH, J.W., EMMONS, L., EMSLIE, R.H., FESTABIANCHET, M., FOSTER, M., FOSTER, S., GARSHELIS, D.L., GATES, C., GIMENEZ-DIXON, M., GONZALEZ, S., GONZALEZ-MAYA, J.F., GOOD, T.C., HAMMERSON, G., HAMMOND, P.S., HAPPOLD, D., HAPPOLD, M., HARE, J., HARRIS, R.B., HAWKINS, C.E., HAYWOOD, M., HEANEY, L.R., HEDGES, S., HELGEN, K.M., HILTON-TAYLOR, C., HUSSAIN, S.A., ISHII, N., JEFFERSON, T.A., JENKINS, R.K., JOHNSTON, C.H., KEITH, M., KINGDON, J., KNOX, D.H., KOVACS, K.M., LANGHAMMER, P., LEUS, K., LEWISON, R., LICHTENSTEIN, G., LOWRY, L.F., MACAVOY, Z., MACE, G.M., MALLON, D.P., MASI, M., MCKNIGHT, M.W., MEDELLÍN, R.A., MEDICI, P., MILLS, G., MOEHLMAN, P.D., MOLUR, S., MORA, A., NOWELL, K., OATES, J.F., OLECH, W., OLIVER, W.R., OPREA, M., PATTERSON, B.D., PERRIN, W.F., POLIDORO, B.A., POLLOCK, C., POWEL, A., PROTAS, Y., RACEY, P., RAGLE, J., RAMANI, P., RATHBUN, G., REEVES, R.R., REILLY, S.B., 
REYNOLDS 3RD, J.E., RONDININI, C., ROSELL-AMBAL, R.G., RULLI, M., RYLANDS, A.B., SAVINI, S., SCHANK, C.J., SECHREST, W., SELF-SULLIVAN, C., SHOEMAKER, A., SILlERO-ZUBIRI, C., DE SILVA, N., SMITH, D.E., SRINIVASULU, C., STEPHENSON, P.J., VAN STRIEN, N., TALUKDAR, B.K., TAYLOR, B.L., TIMMINS, R., TIRIRA, D.G., TOGNELLI, M.F., TSYTSULINA, K., VEIGA, L.M., VIÉ, J.C., WILLIAMSON, E.A., WYATT, S.A., XIE, Y. and YOUNG, B.E., 2008. The status of the world's land and marine mammals: diversity, threat, and knowledge. Science, vol. 322, no. 5899, pp. 225-230. http://dx.doi.org/10.1126/science.1165115. PMid:18845749.

SIMMONS, N.B., 2005. Chiroptera. In: K.D. ROSE and J.D. ARCHIBALD. The Rise of Placental Mammals. Baltimore: Johns Hopkins University Press, pp. 159-174.

SIMMONS, N.B., 2010. Personal Communication. New York: American Museum of Natural History.

SMITH, A.B., 1998. Some notes on roosting behavior in the Indian giant flying fox, Pteropus giganteus, (Brunnich) in a Banyan tree (Ficus benghalensis, Linnaeus, 1758) near Chenniay Nallur, Tamil Nadu, India. United Kingdom: The University of Hull, 159 p. Ph.D. Thesis.
STIER, S.C. and MILDENSTEIN, T.L., 2005. Dietary habits of the world's largest bats: The Philippine Flying Foxes, Acerodon Jubatus and Pteropus Vampyrus Lanensis. Journal of Mammalogy, vol. 86, no. 4, pp. 719-728. http://dx.doi.org/10.1644/15451542(2005)086[0719:DHOTWL]2.0.CO;2.

TEELING, E.C., SPRINGER, M.S., MADSEN, O., BATES, P., O'BRIEN, S.J. and MURPHY, W.J., 2005. A molecular phylogeny for bats illuminates biogeography and the fossil record. Science, vol. 307, no. 5709, pp. 580-584. http://dx.doi. org/10.1126/science.1105113. PMid:15681385.

THATCHER, O., 2004 [viewed 19 October 2004]. Fruit and nectar bat biology [online]. Lubee Bat Conservacy. Available from: http://www.lubee.org/about-biology.aspx

THOMAS, D.W., 1988. The distribution of bats in different ages of Douglast-fir forest. The Journal of Wildlife Management, vol. 52, no. 4, pp. 619-626. http://dx.doi.org/10.2307/3800920.

VAUGHAN, T., RYAN, J. and CZAPLEWSKI, N., 2000. Mammalogy. 4th ed. Toronto: Brooks Cole.

VENDAN, S.E., KALEE, S. and WARAN, B., 2011. Plant dispersal by Indian fling fox Pteropus giganteus in Madurai region, India. Biodiversity, vol. 30, pp. 1810-1813. 